\title{
Editorial - Apresentação
}

A edição n. 2 de 2020 da Revista Prisma Jurídico representa mais um passo deste periódico para efetivação da pesquisa crítica em direito, permitindo a livre circulação e o debate de pensamentos.

Os artigos ora publicados permitem a compreensão dos temas investigados em profundidade, encerrando, qualificada fonte de pesquisa para a comunidade científica.

Os trabalhos publicados são da autoria de professores brasileiros e estrangeiros e por seu elevado grau acadêmico possibilitam qualificada fonte de consulta e discussão da pesquisa brasileira em Direito.

Registramos nossos agradecimentos aos autores e avaliadores pelo cuidadoso trabalho acadêmico que garante a qualidade da revista e sua classificação científica.

Desejamos uma excelente leitura e reiteramos o convite para submissão de suas pesquisas à Revista Prisma Jurídico.

Sejam muito bem vindos.

\author{
(D) Prof. Dr. André Guilherme Lemos Jorge \\ (iD) Prof. Dr. Guilherme Amorim Campos da Silva
}

Editores-Chefes da Revista Prisma Jurídico

Para citar

ABNT NBR 6023:2018

JORGE, André Guilherme Lemos; SILVA, Guilherme Amorim Campos da. Editorial. Prisma Jurídico, São Paulo, v. 19, n. 2, p. 194-194, jul./dez. 2020. http://doi.org/10.5585/prismaj.v19n2.18901. 